\title{
Aktivitas Antibakteri Ekstrak Biji Areca catechu L.Dalam Menghambat Pertumbuhan Salmonella typhi
}

\author{
Mega Selpiah, Aini, Jumari Ustiawaty \\ Jurusan Analis Kesehatan, Politeknik Medica Farma Husada Mataram, Indonesia
}

\begin{tabular}{l}
\hline Article Info \\
\hline Article history: \\
Received Aug $31^{\text {th }}, 2020$ \\
Revised Feb 24 \\
Accepted Feb 24 2021 , 2021 \\
\hline
\end{tabular}

Keyword:

Antibacterial, Areca nut (Areca catechu L.), Salmonella thypi,

$M I C$,

$M B C$,

\begin{abstract}
Typhoid fever is a disease caused by Salmonella typhi bacterial infection which is an endemic disease that can attack many of people and is still a health problem in tropical areas, especially in developing countries including Indonesia. Various prevention, treatment and therapy efforts have been made to reduce the problem of bacterial infection. New alternatives the are continuosly being researched and developed are medicinal uses of herbal plants. One of the plants that can be used as an alternative in the treatment of bacterial infection is the areca nut (Areca catechu L.) which contains antibacterial compounds sush as alkaloids, flavonoids and tannins. The purpose of this study was to determine the antibacterial activity extractof areca nut (Areca catechu L.) in inhibiting the growth of Salmonella typhi, to determine the minimal inhibition concentration (MIC) and minimal bacterisidal concentration (MBC) extractof areca nut (Areca catechu L.) seed extract in inhibits the growth ofSalmonella typhi. The method used in this study is liquid dilution which is described as a bacteriostatic effect and equivalent dilution which is described as a bactericidal effect. This type of research is an experimental laboratory design with the post only control group design using statistical test data analysis version 16. The results of this study were that the betel nut (Areca catechu L.) seed extract was able to inhibit the growth of Salmonella typhi. The minimum inhibity concentration (MIC) of areca nut (Areca catechu L.) seed extract was obtained at a concentration of $1 \%$. The minimal bacterisidal concentration (MBC) extractof areca nut (Areca catechu L.) seed extract was not obtained because in all Nutrient media there was bacterial growth.
\end{abstract}

\footnotetext{
ABSTRAK

Demam tifoid merupakan penyakit yang disebabkan oleh infeksi bakteri Salmonella typhi yang merupakan penyakit endemik yang dapat menyerang banyak orang dan masih menjadi masalah kesehatan di daerah tropis terutama di negara-negara berkembang termasuk Indonesia. Berbagai upaya pencegahan, pengobatan dan terapi yang telah dilakukan untuk mengurangi permasalahan infeksi bakteri. Alternatif baru yang terus diteliti dan dikembangkan adalah pengobatan menggunakan tanaman herbal. Salah satu tanaman yang dapat dimanfaatkan sebagai alternatif dalam pengobatan infeksi bakteri adalah tumbuhan pinang (Areca catechu L.) yang memiliki kandungan senyawa sebagai antibakteri seperti alkaloid, flavonoid dan tanin. Tujuan penelitian ini adalah untuk mengetahui aktivitas antibakteri ekstrak biji buah pinang (Areca catechu L.) dalam menghambat pertumbuhan Salmonella typhi, untuk menentukan Konsentrasi Hambat Minimum (KHM) dan Konsentrasi Bunuh Minimum (KBM) ekstrak biji buah pinang (Areca catechu L.) dalam menghambat pertumbuhan Salmonella typhi.Metode yang digunakan dalam penelitian ini adalah dilusi cair yang digambarkan sebagai efek bakteriostatik dan dilusi padat yang digambarkan sebagai efek bakterisidal. Jenis penelitian ini adalah eksperimentallaboratories dengan desain the post only control group desain dengan menggunakan analisa data uji statistik versi 16. Hasil penelitian ini adalah ekstrak biji buah pinang (Areca catechu L.) mampu menghambat pertumbuhan Salmonella typhi. Konsentrasi Hambat Minimum (KHM) ekstrak biji buah pinang (Areca catechu L.) didapatkan pada konsentrasi 1\%. Konsentrasi Bunuh
} 
Minimum (KBM) ekstrak biji buah pinang (Areca catechu L.) tidak didapatkan karena pada semua media Nutrient agar terdapat pertumbuhan bakteri. Adanya pertumbuhan bakteri tersebut memberikan makna bahwa ekstrak biji buah pinang (Areca catechu L.) hanya mampu menghambat (bakteriostatik) namun tidak mampu membunuh pertumbuhan bakteri.

Kata kunci : Antibakteri, Biji Buah pinang(Areca catechu L.), Salmonella thypi, KHM dan KBM.

\section{Pendahuluan}

Demam tifoid merupakan penyakit yang disebabkan oleh infeksi bakteri Salmonella typhi yang merupakan penyakit endemik yang dapat menyerang banyak orang dan masih menjadi masalah kesehatan di daerah tropis terutama di negara-negara berkembang termasuk Indonesia (Zakiyah, 2013) Berdasarkan data WHO (World Health Organisation) memperkirakan angka insidensi di seluruh dunia sekitar 17 juta jiwa per tahun, angka kematian akibat demam tifoid mencapai 600.000 jiwa dan $70 \%$ nya di Asia. Angka penderita demam tifoid di Indonesia mencapai 81\% per 100.000 jiwa (Depkes, 2013). Pada tahun 2014 diperkirakan 21 juta kasus penderita demam tifoid, 200.000 diantaranya meninggal dunia setiap tahunnya. Tifoid klinis dapat dideteksi di Provinsi NTB dengan prevalensi 1,9\% dan tersebar di seluruh kabupaten/kota (Depkes, 2007) Demam tifoid sendiri akan sangat berbahaya jika tidak segera ditangani secara baik dan benar, bahkan dapat menyebabkan kematian (Organization, 2014).

Bakteri Salmonella typhi termasuk bakteri Gram negatif yang dapat menimbulkan gejala demam tinggi lebih dari seminggu, konstipasi, nyeri abdomen, pusing, mual, muntah, kulit gatal dan timbul bercakbercak berwarna kemerahan, bahkan kehilangan kesadaran (Amiruddin et al., 2017). Infeksi Salmonella typhi pada manusia masuk ke dalam tubuh secara oral melalui mulut bersama makanan dan minuman yang tercemar, ditularkan melalui tangan, lalat, atau serangga lainnya (Brooks et al., 2007)

Tindakan medis yang dapat dilakukan untuk menanggulangi infeksi Salmonella typhi adalah dengan menggunakan antibiotik (Amin, 2014), namun pemberian antibiotik dalam jangka waktu yang lama dapat menimbulkan banyak efek samping seperti reaksi hipersensitivitas, gastrointestinal, kerusakan hati, nefropati, neutropenia, trombositopenia serta gangguan pada kulit (Sarma et al., 2016).

Berbagai upaya pencegahan, pengobatan dan terapi telah banyak dilakukan untuk mengurangi permasalahan infeksi bakteri. Alternatif baru yang terus diteliti dan dikembangkan adalah pengobatan menggunakan tanaman herbal atau tanaman obat (Mi. Baiti et al., 2018). Salah satu tanaman yang dapat dimanfaatkan sebagai alternatif dalam pengobatan infeksi bakteri adalah tumbuhan pinang (Areca catechu L.) merupakan salah satu jenis tumbuhan palma yang memiliki senyawa berkhasiat sebagai antibakteri seperti alkaloid, flavonoid dan tanin (Jaiswal et al., 2011).

Secara tradisional pinang dimanfaatkan sebagai obat pada anoreksia, pinang muda dicampur dengan daun sirih untuk menguatkan gigi serta obat yang digunakan untuk mengecilkan rahim setelah melahirkan, biji pinang (Areca catechu L.)juga digunakan dalam ramuan untuk mengobatisakit disentri, diare berdarah, dan kudisan(Meiyanto et al., 2008). Pinang (Areca catechu L.) juga memiliki khasiat medis, diantaranya memiliki efek terapi sepertiantihelmintes, anti-oksidan, antihipertensi, antimikrobial dan penyembuh luka (Mi. Baiti et al., 2018). 
Beberapa penelitian melaporkan bahwa ekstrak kering biji buah pinang (Areca catechu L.) dapat menghambat pertumbuhan bakteri Klebsiela (gram negatif, non motil dan fakultatif anaerob) dan Pseudomonas aeruginosa (bakteri gram negatif, motil, dan aerob obligat) secara efektif (Baby \& Raphael, 2014) serta Pengaruh pemberian ekstrak biji buah pinang (Areca catechu L.) terhadap pertumbuhan Staphylococus aureus secara in vitro(M. Baiti et al., 2018).

Adanya senyawa yang berkhasiat sebagai antibakteri pada biji buah pinang (Areca catechu L.). Penelitian sebelumya yang dilakukan oleh (Rosyidah, 2016) tentang konsentrasi hambatan minimum ( KHM) biji buah pinang terhadap Salmonella typhi didapat bahwa tidak terjadi pertumbuhan pada konsentrasi 100\%; 50\%; 25\%; $12,5 \%$ dan terjadi pertumbuhan pada konsentrasi 3.125 dan 1,6 \% pada media Macconkey agar plate. Perbedaan penelitian ini adalah untuk mengukur daya bunuh ekstrak biji buah pinang dalam konsentrasi yang lebih rendah dan daya hambat ekstrak biji buah pinang pada media dilusi cair dan menggunakan media dilusi padat untuk mengukur Konsentrasi Bunuh Minumum (KBM). Berdasarkan hal tersebut penulis tertarik untuk melakukan penelitian lebih lanjut mengenai aktivitas antibakteri ekstrak biji buah pinang (Areca catechu L.) dalam menghambat pertumbuhan bakteri Salmonella typhi.

\section{Metode Penelitian}

Jenis penelitian yang digunakan dalam penelitian ini adalah eksperimental laboratories dengan menggunakan post test only control group desain. Data dikumpulkan secara observasi. Data dalam penelitian ini merupakan data primer. Data dikumpulkan dengan melakukan uji kosentrasi hambat minimum (KHM) dari ekstrak biji buah pinang (Areca catechu L.) terhadap bakteri salmonella tiyphi dengan metode dilusi dan metode padat. Bahan yang digunakan dalam penelitian ini adalah biji buah pinang muda yang dikeringkan. Penelitian ini menggunakan 11 konsentrasi yaitu : 1\%, 5\%, 7,5\%, 10\%, 12,5\%, 15\%, 20\%, 25\%, $30 \%$ termasuk kontrol positif Chloramfenicol dan kontrol negatif (aquadest + media). Data hasil dianalisis dengan menggunakan program SPSS versi 16. Kemudian uji non parametrik yaitu uji Kruskal-Walls untuk melihat perbedaan secara berbeda bermakna

\section{Hasil Penelitian dan Pembahasan}

Adapun hasil uji konsentrasi hambat minimum (KHM) ekstrak biji buah pinang (Areca catechu L.) dalam menghambat pertumbuhan Salmonella typhi disajikan pada tabel 1 tabel 1 dibawah ini :

Tabel 1. Hasil Uji Konsentrasi Hambat Minimum (KHM) dari Ekstrak Biji Buah Pinang (Areca catechu L.) dalam Menghambat Pertumbuhan Salmonella typhi dengan Metode Dilusi Cair.

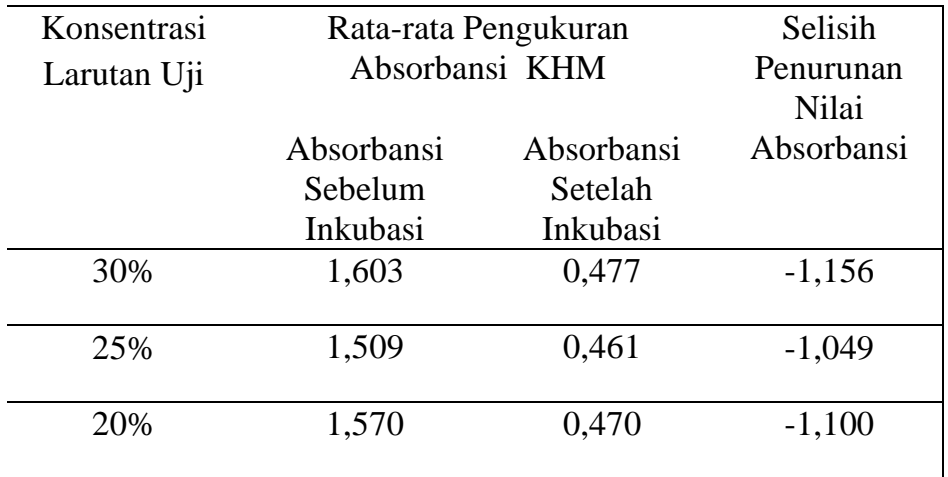




\begin{tabular}{cccc|}
\hline $15 \%$ & 1,623 & 0,95 & $-0,673$ \\
\hline $12,5 \%$ & 1,784 & 1,039 & $-0,744$ \\
\hline $10 \%$ & 1,717 & 1,243 & $-0,473$ \\
\hline $7,5 \%$ & 1,898 & 1,334 & $-0,564$ \\
\hline $5 \%$ & 1,871 & 1,408 & $-0,463$ \\
\hline $1 \%$ & 1,908 & 1,424 & $-0,484$ \\
\hline $\mathrm{K}(+)$ & 0,893 & 0,49 & $-0,403$ \\
\hline $\mathrm{K}(-)$ & 1,272 & 1,272 & $-0,000$ \\
\hline
\end{tabular}

Sumber : Data primer 2020

Berdasarkan tabel 1 terlihat bahwa rata-rata hasil pengukuran KHM metode dilusi cair terjadi penurunan nilai absorbansi setelah diinkubasi selama 24 jam pada semua konsentrasi. Penurunan paling tinggi didapatkan pada konsentrasi 30\% dengan nilai hambatan sebesar -1,156. Sedangkan penurunan paling rendah didapatkan pada konsentrasi 5\% dengan nilai hambatan sebesar -0,463.

Tabel 2. Hasil Uji Konsentrasi Bunuh Minimum (KBM)

\begin{tabular}{cccc}
\hline $\begin{array}{c}\text { Konsentrasi } \\
\text { Larutan Uji }\end{array}$ & \multicolumn{3}{c}{ Hasil Uji KBM } \\
& $\begin{array}{c}\text { Pengulangan } \\
\text { I }\end{array}$ & $\begin{array}{c}\text { Pengulangan } \\
\text { II }\end{array}$ & $\begin{array}{c}\text { Pengulangan } \\
\text { III }\end{array}$ \\
\hline $30 \%$ & + & + & + \\
\hline $25 \%$ & + & + & + \\
\hline $20 \%$ & + & + & + \\
\hline $15 \%$ & + & + & + \\
\hline $12,5 \%$ & + & + & + \\
\hline $10 \%$ & + & + & + \\
\hline $7,5 \%$ & + & + & + \\
\hline $5 \%$ & + & + & + \\
\hline $1 \%$ & + & + & - \\
\hline $\mathrm{K}(+)$ & - & - & - \\
\hline $\mathrm{K}(-)$ & - & - &
\end{tabular}

Berdasarkan table 2. menunjukkan bahwa terjadi pertumbuhan bakteri pada media yang dilakukan penggoresan terhadap semua konsentrasi larutan uji ekstrak biji buah pinang (Areca catechu L.). Pertumbuhan bakteri dapat dilihat bahwa terjadi pada semua konsentrasi dan pada setiap pengulangan sedangkan pada kontrol positif dan kontrol negatif tidak terjadi pertumbuhan bakteri.

Hasil uji Normalitas Kolmogorov Smirnov menunjukkan bahwa angka signifikansi data (sig.2 tailed) > 0.05 yaitu 0,425 yang artinya data tersebut terbukti berdistribusi normal. Hasil uji Levane menunjukkan nilai p (Sig.) sebesar $0,008(0,008<0,05)$ yang berarti bahwa data tersebut dinyatakan tidak homogen. Berdasarkan hasil uji normalitas dan uji homogenitas, diketahui data berdistribusi normal dan tidak homogen. 
Tabel 3 Hasil Uji Kruskal Wallis

\begin{tabular}{|l|r|}
\hline & \multicolumn{1}{|c|}{ KHM } \\
\hline Chi-Square & 29,461 \\
0Df & 10 \\
Asymp. Sig. &, 001 \\
\hline
\end{tabular}

a. Kruskal Wallis Test

b. Grouping Variable: Perlakuan

Berdasarkan tabel 3 terlihat bahwa hasil uji Kruskal Wallis menunjukkan nilai sig. $(0,001)$ atau<0,05, artinya ekstrak biji buah pinang (Areca catechu L.) mampu menghambat pertumbuhan Salmonella typhi. Hasil dari uji Kruskal Wallis terlihat perbedaan secara berbeda bermakna pada setiap kelompok konsentrasi

\section{Pembahasan}

Penelitian uji aktivitas antibakteri ekstrak biji buah pinang (Areca catechu L.) yang dilakukan dengan metode dilusi cair dan dilusi padat bertujuan untuk mengetahui aktivitas antibakteri terhadap bakteri Salmonella typhi. Metode dilusi cair digunakan untuk mengukur Konsentrasi Hambat Minimum (KHM) yang digambarkan sebagai efek bakteriostatik (Astutiningsih et al., 2014). Sedangkan metode dilusi padat digunakan untuk mengukur Kadar Bunuh Minimum (KBM) yang digambarkan sebagai efek bakterisida (Astutiningsih et al., 2014). Adapun hasil uji KHM ekstrak biji buah pinang (Areca catechu L.) dalam menghambat pertumbuhan Salmonella typhi dapat dilihat pada tabel1.

Berdasarkan tabel 1 terlihat bahwa rata-rata hasil pengukuran KHM metode dilusi cair terjadi penurunan nilai absorbansi setelah diinkubasi selama 24 jam pada semua konsentrasi. Penurunan paling tinggi didapatkan pada konsentrasi 30\% dengan nilai hambatan sebesar -1,156. Sedangkan penurunan paling rendah didapatkan pada konsentrasi 5\% dengan nilai hambatan sebesar -0,463. Penurunan nilai absorbansi yang dihasilkan pada setiap konsentrasi dikarenakan adanya senyawa yang terkandung dalam biji buah pinang (Areca catechu L.) seperti alkaloid, flavonoid dan tanin. Mekanisme kerja phitocemical Alkaloid adalah dengan cara mengganggu komponen penyusun peptidoglikan pada sel bakteri, sehingga lapisan dinding sel tidak terbentuk secara utuh dan menyebabkan kematian sel tersebut. Phitochemical Flavonoid bekerja dengan mengganggu aktivitas transpeptidase peptidoglikan sehingga pembentukan dinding sel terganggu dan sel akan mengalami lisis. Phitochemical Tanin bekerja dengan cara mendenaturasi protein yang terdapat pada dinding sel (Ayunastiti, 2013). Penelitian ini sejalan dengan penelitian (Jaiswal et al., 2011) menyatakan bahwa pada biji buah pinang (Areca catechu L.) memiliki senyawa yang dijadikan khasiat antibakteri adalah alkaloid, flavonoid dan tanin.

Berdasarkan tabel 2 terlihat adanya pertumbuhan bakteri pada semua media Nutrient Agar yang dilakukan penggoresan terhadap semua konsentrasi larutan uji ekstrak biji buah pinang (Areca catechu L.). Untuk mengetahui Konsentrasi Bunuh Minimum (KBM) dari hasil uji Konsentrasi Hambat Minimum (KHM) dapat dilihat pada tabel 2 dimana hasil uji KBM pada semua konsentrasi dan pada setiap pengulangan terlihat adanya pertumbuhan bakteri. Adanya pertumbuhan bakteri tersebut memberikan makna bahwa ekstrak biji buah pinang (Areca catechu L.) hanya mampu menghambat (bakteriostatik) namun tidak mampu membunuh pertumbuhan bakteri Salmonell typhi (Astutiningsih et al., 2014).Kemampuan suatu 
bahan antimikroba dalam menghambat pertumbuhan mikroorganisme tergantung pada konsentrasi antimikroba. Artinya semakin tinggi jumlah konsentrasi antimikroba maka semakin sedikit koloni bakteri yang tumbuh (Soleha, 2015). Hasil penelitian ini sesuai dengan penelitian yang dilakukan oleh Santoso (2012) yang menyatakan bahwa semakin tinggi konsentrasi ekstrak, semakin menurun jumlah koloni bakteri yang tumbuh(Santoso \& Hirzi, 2013).

Selanjutnya data nilai KHM (Konsentrasi Hambat Minimum) dianalisis dengan uji statistik SPSS versi 16 yaitu menggunakan uji Kolmogorov Smirnov untuk mengetahui normalitas data. Berdasarkan tabel 3 menunjukkan bahwa angka signifikansi data (sig.2 tailed) > 0.05 yaitu 0,425 yang artinya data tersebut terbukti berdistribusi normal.

Hasil uji Levane menunjukkan nilai p (Sig.) sebesar 0,008 $(0,008<0,05)$ yang berarti bahwa data tersebut dinyatakan tidak homogen. Berdasarkan hasil uji normalitas dan uji homogenitas, diketahui data berdistribusi normal dan tidak homogen. Selanjutnya dilakukan uji Kruskal Wallis untuk mengetahui pengaruh ekstrak biji buah pinang (Areca catechu L.) terhadap pertumbuhan Salmonella typhi, nilai KHM dan nilai KBM.

Berdasarkan tabel 3 terlihat bahwa hasil uji Kruskal Wallis menunjukkan nilai sig. $(0,001)$ atau $<0,05$, artinya ekstrak biji buah pinang (Areca catechu L.) mampu menghambat pertumbuhan Salmonella typhi.Dari hasil uji Kruskal Wallis terlihat perbedaan secara berbeda bermakna pada setiap kelompok konsentrasi.

Pada konsentrasi 30\%, 25\% dan 20\% sama-sama menunjukkan perbedaan tidak berbeda bermakna yang berarti bahwa dalam penelitian ini bisa digunakan konsentrasi rendah atau konsentrasi $20 \%$ untuk dijadikan alternatif pengobatan demam tifoid yang disebabkan oleh bakteri Salmonella typhi. Karena pada konsentrasi $20 \%$ jumlah toksisitas yang terkandung berbeda atau lebih sedikit dibandingkan dengan jumlah toksisitas yang terkandung dalam konsentrasi $30 \%$.

Sedangkan pada konsentrasi $5 \%$ dan K (+) sama-sama menunjukkan perbedaan tidak berbeda bermakna yang berarti bahwa dalam penelitian ini bisa digunakan ekstrak biji buah pinang (Areca catechu L.) dengan konsentrasi 5\% untuk dijadikan alternatif pengobatan demam tifoid yang disebabkan oleh bakteri Salmonella typhi karena nilai hambatan yang dihasilkan pada konsentrasi 5\% sebesar -0,463 menunjukkan selisih tidak jauh dengan nilai hambatan pada kontrol positif yaitu sebesar -0,403. Penelitian ini sejalan dengan penelitian Winarsih dkk (2015) yang menyatakan antara setiap perlakuan menunjukkan terdapat perbedaan berbeda bermakna antara setiap konsentrasi, tetapi pada konsentrasi $20 \%$, 25\% dan $30 \%$ tidak berbeda signifikan atau satu sama lain(Winarsih et al., 2015).

Menurut (Siska Nuryanti et al., 2019) Komponen kimia dari ekstrak fermentat isolate fungi endofit biji pinang yang dapat menghambat pertumbuhan bakteri uji Escherichia coli dan Salmonella thypi adalah golongan senyawa alkaloid, tannin, dan polifenol. Menurut (Masduki, 1996)- Sensitivitas Salmonella terhadap biji buah pinang bahwa kandungan tannin juga mempunyai daya antibakteri dengan cara mempresipitasi protein, karena diduga tannin mempunyai efek yang sama dengan senyawa fenolik. Efek antibakteri tanin antara lain melalui: reaksi dengan membran sel,inaktivasi enzim, dan destruksi atau inaktivasi fungsi materi genetik. 


\section{Kesimpulan}

Ekstrak biji buah pinang (Areca catechu L.) mampu menghambat pertumbuhan Salmonella typhi. dengan Konsentrasi Hambat Minimum (KHM) pada ekstrak biji buah pinang (Areca catechu L) pada kosentrasi uji $1 \%$ sedangkan kosentrasi bunuh minimum tidak didapatkan karena pada semua media Nutrient agar terjadi pertumbuhan. Ekstrak biji buah pinang (Areca catechu L.) hanya bersifat menghambat (bakteriostatik) namun tidak membunuh (bakteriosidal) dari Salmonell typhi dalam konsentrasi uji penelitin ini

\section{Daftar Pustaka}

Amin, L. Z. (2014). Pemilihan antibiotik yang rasional. Medicinus, 27(3), 40-45.

Amiruddin, R. R., Darniati, D., \& Ismail, I. (2017). Isolasi dan Identifikasi Salmonella sp pada Ayam Bakar di Rumah Makan Kecamatan Syiah Kuala Kota Banda Aceh. JURNAL ILMIAH MAHASISWA VETERINER, 1(3), 265-274.

Astutiningsih, C., Setyani, W., \& Hindratna, H. (2014). Uji Daya Antibakteri dan Identifikasi Isolat Senyawa Katekin dari Daun Teh (Camellia sinensis L. var Assamica). Jurnal Farmasi Sains Dan Komunitas, 11(2), 50-57.

Ayunastiti, R. S. (2013). Potensi Ekstrak Etanol Biji Pinang (Areca Catechu L.) Sebagai Kandidat Antibakteri Terhadap Pertumbuhan Bakteri Pada Jerawat.

Baby, A. A., \& Raphael, K. R. (2014). Potential antimicrobial, anthelmintic and antioxidant properties of Areca catechu L. root. International Journal of Pharmacy and Pharmaceutical Sciences, 6(6), 486489.

Baiti, M., Elfrida, S., \& Lipinwati, L. (2018). PENGARUH PEMBERIAN EKSTRAK ETHANOL BIJI BUAH PINANG (ARECA CATECHU L.) TERHADAP PERTUMBUHAN STAPHYLOCOCUS AUREUS SECARA IN VITRO. JAMBI MEDICAL JOURNAL" Jurnal Kedokteran Dan Kesehatan", 6(1), 10-19.

Baiti, Mi., Elfrida, S., \& Lipinwati, L. (2018). Pengaruh Pemberian Ekstrak Ethanol Biji Buah Pinang (Areca Catechu L.) Terhadap Pertumbuhan Staphylococus Aureus Secara in Vitro. JAMBI MEDICAL JOURNAL “Jurnal Kedokteran Dan Kesehatan,” 6(1), 10-19. https://doi.org/10.22437/jmj.v6i1.4817

Brooks, G. F., Butel, J. S., Morse, S. A., Mikrobiologi Kedokteran Jawetz, M., \& Adelberg, E. (2007). ke-23. Penerbit Buku Kedokteran EGC, Jakarta.

Depkes. (2007). Laporan Riskesdas 2007 Provinsi Nusa Tenggara Barat. Badan Penelitian Dan Pengembangan Kesehatan Tahun 2008.

Depkes, R. I. (2013). Sistematika pedoman pengendalian penyakit demam tifoid. Jakarta: Direktorat Jendral.

Jaiswal, P., Kumar, P., Singh, V. K., \& Singh, D. K. (2011). Areca catechu L.: A Valuable Herbal Medicine Against Different. Research Journal of Medicinal Plant, 5(2), 145-152.

Masduki. (1996). Efek Antibakteri Ekstrak Biji Pinang (Areca catechu) Terhadap S.aureus dan E.coli in 
ISSN: 2656-2456 (Online)

vitro.

Meiyanto, E., Susidarti, R. A., Handayani, S., \& Rahmi, F. (2008). Ekstrak etanolik biji buah pinang (Areca catechu L.) mampu menghambat proliferasi dan memacu apoptosis sel MCF-7. Majalah Farmasi Indonesia, 19(1), 12-19.

Organization, W. H. (2014). Maternal mortality: fact sheet: to improve maternal health, barriers that limit access to quality maternal health services must be identified and addressed at all levels of the health system. World Health Organization.

Rosyidah. (2016). The Effect of Areca Seed Extract (Areca catechu L.) on the growth of Salmonella typhi bacteria in vitro.

Santoso, K. R. A., \& Hirzi, A. (2013). Efektivitas Ekstrak Etanol Biji Pinang (Areca catechu Lin.) Terhadap Pertumbuhan Bakteri Streptococcus mutans Secara In Vitro. Universitas Brawijaya. Program Studi Pendidikan Dokter Gigi. Fakultas Kedokteran. Malang.

Sarma, N., Giancaspro, G., \& Venema, J. (2016). Dietary supplements quality analysis tools from the United States Pharmacopeia. Drug Testing and Analysis, 8(3-4), 418-423.

Siska Nuryanti, Rusli, \& Risma Astuti. (2019). Potensi Fungi Endofit Biji Pinang Sebagai Antibakteri Terhadap Escherichia coli dan Salmonella thypi. Green Medical Journal, 1(1), 87-96. https://doi.org/10.33096/gmj.v1i1.23

Soleha, T. U. (2015). Uji kepekaan terhadap antibiotik. Juke Unila, 5(9), 119-123.

Winarsih, S., Purwantiningrum, D. A., \& Wardhani, A. S. (2015). Efek Antibakteri Ekstrak Daun Katuk (Sauropus androgynus) terhadap Pertumbuhan Salmonella Typhi secara In Vitro. Mutiara Medika: Jurnal Kedokteran Dan Kesehatan, 15(2), 96-103.

Zakiyah. (2013). DAYA HAMBAT EKSTRAK BATANG PISANG AMBON (Musa paradisiaca var. sapientum) TERHADAP PERTUMBUHAN BAKTERI Staphylococcus aureus DAN Streptococcus viridans. 